Fixed Point Theory, 22(2021), No. 2, 645-662

DOI: $10.24193 /$ fpt-ro.2021.2.42

http://www.math.ubbcluj.ro/ nodeacj/sfptcj.html

\title{
APPROXIMATING COMMON FIXED POINT VIA ISHIKAWA'S ITERATION
}

\author{
R. GOPI* AND V. PRAGADEESWARAR**
}

*Department of Mathematics, Amrita School of Engineering, Amrita Vishwa Vidyapeetham, Coimbatore-641112, Tamil Nadu, India

E-mail: r_gopi@cb.amrita.edu

** Department of Mathematics, Amrita School of Engineering, Amrita Vishwa Vidyapeetham, Coimbatore-641112, Tamil Nadu, India

E-mail: v_pragadeeswarar@cb.amrita.edu

Abstract. In this work, we approximate a common fixed point of mappings $F, G: M \cup N \rightarrow M \cup N$, satisfying the conditions

(1) $G(M) \subseteq M, G(N) \subseteq N, F(M) \subseteq M$ and $F(N) \subseteq N$;

(2) $\|F u-G v\| \leq\|u-v\|$ for $u \in M, v \in N$; and

(3) $\|F u-G v\| \leq\|u-v\|$ for $u \in N, v \in M$,

where $M$ and $N$ are nonempty bounded closed convex subsets of a uniformly convex Banach space. We consider Ishikawa iteration associated with $F$ and $G$ and von Neumann sequence associated with Ishikawa iteration to approximate the common fixed point of $F$ and $G$. We prove convergent results for common fixed point of $F$ and $G$. Finally, we give corollaries on common best proximity point for cyclic mappings.

Key Words and Phrases: Nonexpansive mappings, best proximity points, fixed points, Banach space, Von Neumann sequences.

2020 Mathematics Subject Classification: 47H10, 46B20, 54H25.

Acknowledgements. The authors would like to thank the National Board for Higher Mathematics (NBHM), DAE, Govt. of India for providing a financial support under the grant no. 02011/22/2017/R\&D II/14080.

\section{REFERENCES}

[1] A. Abkar, M. Gabeleh, Global optimal solutions of noncyclic mappings in metric spaces, J. Optim. Theory Appl., 153(2012), 298-305.

[2] A. Anthony Eldred, W.A. Kirk, P. Veeramani, Proximal normal structure and relatively nonexpansive mappings, Studia Mathematica, 171(2005), 283-293.

[3] A. Anthony Eldred, A. Praveen, Convergence of Mann's iteration for relatively nonexpansive mappings, Fixed Point Theory, 18(2017), 1-9.

[4] A. Anthony Eldred, P. Veeramani, Existence and convergence of best proximity points, J. Math. Anal. Appl., 323(2006), 1001-1006.

[5] H.H. Bauschke, J.M. Borwein, On the convergence of von Neumann's alternating projection algorithm for two sets, Set-Valued Var. Anal., 1(1993), 185-212. 
[6] V. Berinde, On the convergence of the Ishikawa iteration in the class of quasi contractive operators, Acta Math. Univ. Comenian., 73(2004), 119-126.

[7] S.C. Bose, Common fixed points of mappings in a uniformly convex Banach space, J. London Math. Soc., 18(1978), 151-156.

[8] C.E. Chidume, Geometric Properties of Banach Spaces and Nonlinear Iterations, Springer, London, 2009.

[9] Lj. B. Ćirić, S. Ume, M.S. Khan, On the convergence of the Ishikawa iterates to a common fixed point of two mappings, Arch. Math., 39(2003), 123-127.

[10] W.G. Dotson, On the Mann iterative process, Trans. Amer. Math. Soc., 149(1970), 65-73.

[11] M. Gabeleh, Common best proximity pairs in strictly convex Banach spaces, Georgian Math. J., 24(2017), 363-372.

[12] M. Gabeleh, Convergence of Picard's iteration using projection algorithm for noncyclic contractions, Indag. Math., 30(2019), no. 1, 227-239.

[13] H.S. Hundal, An alternating projection that does not converges in norm, Nonlinear Anal., $\mathbf{5 7}(2004), 35-61$.

[14] P.E. Maingé, Approximation methods for common fixed points of nonexpansive mappings in Hilbert spaces, J. Math. Anal. Appl., 325(2007), 469-479.

[15] J. Von Neumann, Functional Analysis, Vol. II, Princton University Press, 1950.

[16] S. Rajesh, P. Veeramani, Best proximity point theorems for asymptotically relatively nonexpansive mappings, Numer. Funct. Anal. Optim., 37(2016), 80-91.

[17] R.A. Rashwan, On the convergence of Mann iterates to common fixed point for a pair of mappings, Demonstratio Math., 23(1990), 709-712.

[18] R.A. Rashwan, A.M. Saddeek, On the Ishikawa iteration process in Hilbert spaces, Collect. Math., 45(1994), 45-52.

[19] H.F. Senter, W.G. Dotson, Approximating fixed points of nonexpansive mappings, Proc. Amer. Math. Soc., 44(1974), 375-380

[20] Y. Song, R. Chen, Iterative approximation to common fixed points of nonexpansive mappings sequences in reflexive Banach spaces, Nonlinear Anal., 66(2007), 591-603.

[21] Yu-Chao Tang, Ji-Gen Peng, Li-Wei Liu, A cyclic and simultaneous iterative algorithm for the multiple split common fixed point problem of demicontractive mappings, Bull. Korean Math. Soc., 51(2014), 1527-1538.

[22] G. Zhaohui, L. Yongjin, Approximation methods for common fixed points of mean nonexpansive mappings in Banach spaces, Fixed Point Theory and Appl., 2008(2008), no. 1, 471532.

[23] B. Zlatanov, Error estimates for approximating best proximity points for cyclic contractive maps, Carpathian J. Math., 32(2016), no. 2, 265-270.

Received: October 3, 2019; Accepted: May 16, 2020. 